\title{
Evaluation of in vitro production rates of bovine embryos using melatonin- supplemented culture medium
}

\author{
Avaliação das taxas de produção in vitro de embriões bovinos usando meio de cultivo suplementado \\ com melatonina
}

Evaluación de las tasas de producción in vitro de embriones bovinos utilizando medio de cultivo suplementado con melatonina

Received: 27/04/2021 | Reviewed: 05/05/2021 | Accept: 11/05/2021 | Published: 27/05/2021

\author{
Ricardo Magalhães \\ ORCID: https://orcid.org/0000-0001-9816-9733 \\ Universidade Paranaense, Brazil \\ E-mail: ricardomagalhaesvet@gmail.com \\ Carlos Renato de Freitas Guaitolini \\ ORCID: https://orcid.org/0000-0002-9619-9186 \\ Universidade Paranaense, Brazil \\ E-mail: carlosrfg@hotmail.com \\ Márcio Luiz Denck Tramontin \\ ORCID: https://orcid.org/0000-0003-1884-217X \\ Universidade Paranaense, Brazil \\ E-mail: marcioldtramontin@gmail.com \\ Danielle Andressa Oliveira Sestari \\ ORCID: https://orcid.org/0000-0002-7003-3997 \\ Universidade Paranaense, Brazil \\ E-mail: dani_sestari@hotmail.com \\ Bruno Argenton de Barros \\ ORCID: https://orcid.org/0000-0003-0344-2173 \\ Universidade Paranaense, Brazil \\ E-mail: brunoargentonbarros@ hotmail.com \\ Alecsandro Silva de Lima Elias \\ ORCID: https://orcid.org/0000-0002-7922-6007 \\ Universidade Paranaense, Brazil \\ E-mail: alecsandroelias@gmail.com \\ Alyson Liberali Araujo \\ ORCID: https://orcid.org/0000-0001-9067-1921 \\ Universidade Paranaense, Brazil \\ E-mail: liberalialyson@gmail.com \\ Daniel Campos Giosa \\ ORCID: https://orcid.org/0000-0001-5262-0840 \\ Universidade Paranaense, Brazil \\ E-mail: danielsrs_vet@hotmail.com \\ Auly Beatriz Trindade \\ ORCID: https://orcid.org/0000-0002-2934-9332 \\ Universidade Paranaense, Brazil \\ E-mail: aulytrindade@gmail.com \\ Rosiara Rosaria Dias Maziero \\ ORCID: https://orcid.org/0000-0003-0314-8409 \\ Universidade Paranaense, Brazil \\ E-mail: rosiaramaziero@gmail.com
}

\begin{abstract}
In this study, we aimed to evaluate the rate of bovine embryo production by using $50 \mathrm{ng} / \mathrm{mL}$ melatonin supplementation in in vitro culture medium. For this, oocytes from slaughterhouse ovaries were matured in vitro in TCM-199 medium with Earle's balanced salt solution $+10 \% \mathrm{SFB}, \mathrm{FSH}$, and $\mathrm{LH}$ in an atmosphere of $5 \% \mathrm{CO}_{2}$. Twenty-four hours after IVM, the oocytes underwent in vitro fertilization in human tubal fluid under the same conditions as above, for $18 \mathrm{~h}$. Semen was fractionated by Percoll gradient centrifugation and the concentration of sperm was adjusted to $1 \times 10 \% \mathrm{~mL}$. Probable zygotes were then divided into two groups: the control group grown in drops of $90 \mu \mathrm{L}$ SOFaa medium $+0.6 \%$ BSA $+2.5 \% \mathrm{SFB}$, in an atmosphere of $5 \% \mathrm{CO}_{2}, 90 \% \mathrm{~N} 2$, and a melatonin group (Mel), similarly cultured in $90 \mu \mathrm{L}$ drops of SOFaa medium $+0.6 \% \mathrm{BSA}+2.5 \% \mathrm{SFB}+50 \mathrm{ng} / \mathrm{mL}$ melatonin . Cleavage rates were assessed on day 3 (D3). On D7, blastocyst formation rates were evaluated. Eight routines were performed (320 oocytes per routine). Data were analyzed with ANOVA, followed by Tukey's range test using a general linear model. The level of statistical significance was set at 5\%. There were no differences in the rates of
\end{abstract}


cleavage or blastocyst formation between the control and melatonin groups $(\mathrm{P}>0.05)$. Thus, under the conditions used in this study, supplementation with melatonin did not yield benefits in increasing the rate of in vitro bovine embryo production.

Keywords: Blastocysts; Bovine; In vitro culture; Melatonin; In vitro embryo production.

\section{Resumo}

Neste estudo, objetivou-se avaliar a taxa de produção de embriões bovinos utilizando suplementação de melatonina 50 $\mathrm{ng} / \mathrm{mL}$ em meio de cultivo in vitro. Para isso, oócitos de ovários de abatedouro foram maturados in vitro em meio TCM-199 com solução salina balanceada de Earle + 10\% SFB, FSH e LH em uma atmosfera de 5\% de CO2. Vinte e quatro horas após a MIV, os oócitos foram submetidos à fertilização in vitro em fluido tubárico humano nas mesmas condições acima, por 18 horas. O sêmen foi fracionado por centrifugação em gradiente de Percoll e a concentração espermática ajustada para $1 \times 10 \% \mathrm{~mL}$. Os prováveis zigotos foram então divididos em dois grupos: o grupo controle cultivado em gotas de $90 \mu \mathrm{L}$ de meio SOFaa $+0,6 \%$ de BSA $+2,5 \%$ de SFB, em uma atmosfera de $5 \%$ de CO2, 90\% de N2, e um grupo de melatonina (Mel), da mesma forma cultivadas em gotas de $90 \mu \mathrm{L}$ de meio SOFaa $+0,6 \%$ BSA $+2,5 \%$ SFB $+50 \mathrm{ng} / \mathrm{mL}$ de melatonina. As taxas de clivagem foram avaliadas no dia 3 (D3). No D7, as taxas de formação de blastocisto foram avaliadas. Oito rotinas foram realizadas (320 oócitos por rotina). Os dados foram analisados por ANOVA, seguido pelo teste de intervalo de Tukey usando um modelo linear geral. O nível de significância estatística foi estabelecido em 5\%. Não houve diferenças nas taxas de clivagem ou formação de blastocisto entre os grupos controle e melatonina $(\mathrm{P}>0,05)$. Assim, nas condições utilizadas neste estudo, a suplementação com melatonina não trouxe benefícios no aumento da taxa de produção in vitro de embriões bovinos.

Palavras-chave: Blastocistos; Bovino; Cultivo in vitro; Melatonina; Produção de embriões in vitro.

\section{Resumen}

En este estudio, nuestro objetivo fue evaluar la tasa de producción de embriones bovinos mediante el uso de suplementos de melatonina $50 \mathrm{ng} / \mathrm{mL}$ en medio de cultivo in vitro. Para ello, se maduraron in vitro ovocitos de ovarios de matadero en medio TCM-199 con solución salina equilibrada de Earle + SFB, FSH y LH al 10\% en una atmósfera de $\mathrm{CO} 2$ al 5\%. Veinticuatro horas después de la MIV, los ovocitos se sometieron a fertilización in vitro en líquido tubárico humano en las mismas condiciones que antes, durante $18 \mathrm{~h}$. El semen se fraccionó mediante centrifugación en gradiente de Percoll y la concentración de espermatozoides se ajustó a 1 x 106 / ml. Luego, los cigotos probables se dividieron en dos grupos: el grupo de control crecido en gotas de $90 \mu \mathrm{L}$ de medio SOFaa $+0.6 \%$ $\mathrm{BSA}+2.5 \% \mathrm{SFB}$, en una atmósfera de $5 \% \mathrm{CO} 2,90 \% \mathrm{~N} 2$ y un grupo de melatonina (Mel), de manera similar cultivado en gotas de $90 \mu \mathrm{L}$ de medio SOFaa + BSA al 0,6\% + SFB al 2,5\% + $50 \mathrm{ng} / \mathrm{mL}$ de melatonina. Las tasas de escisión se evaluaron el día 3 (D3). En D7, se evaluaron las tasas de formación de blastocistos. Se realizaron ocho rutinas (320 ovocitos por rutina). Los datos se analizaron con ANOVA, seguido de la prueba de rango de Tukey utilizando un modelo lineal general. El nivel de significación estadística se estableció en 5\%. No hubo diferencias en las tasas de escisión o formación de blastocistos entre los grupos de control y melatonina (P> 0,05). Por lo tanto, en las condiciones utilizadas en este estudio, la suplementación con melatonina no produjo beneficios en el aumento de la tasa de producción de embriones bovinos in vitro.

Palabras clave: Blastocistos; Bovino; Cultivo in vitro; Melatonina; Producción de embriones in vitro.

\section{Introduction}

In Brazil, 375,503 bovine embryos were produced in 2017, of which 345,528 were generated in vitro, accounting for $34.8 \%$ of global production. In vitro embryo production has consolidated itself as the technique of choice for the production of bovine embryos, accounting for the highest percentage of embryos produced, not only in beef Zebu breeds, but also in other market segments (Taurine and Zebu cattle, beef, and milk). The availability of sexed semen from mid-2005, associated with progressive improvements in the efficiency of in vitro production embryo, boosted its adoption in dairy breeds (Pontes et al., 2011; Vianna, 2011). As a consequence, the national market, characterized in 2007 by the predominance of Zebu and beef breeds, registered in 2017 a greater production of embryos in Taurine breeds or their crosses, and in dairy breeds. Thus, the profile of activity in Brazil has become similar to that observed in other regions of the world (Gonçalves \& Vianna, 2019).

Thus, in vitro production embryo has become a valuable technology for assisted reproduction in cattle breeding systems. However, even with the remarkable innovations developed involving this system, the greatest obstacles to the full success of this biotechnology are low rates of post-transfer pregnancy and the greater sensitivity of embryos to cryopreservation (Maziero et al., 2016). This leads us to believe that in vitro production embryo systems induce embryonic 
changes that prevent full-term pregnancy. Other authors have described morphological changes between embryos in vivo and in vitro, such as increases in cytoplasmic lipid droplets and mitochondrial alterations (Sudano et al., 2011).

In vitro production embryo involves three stages: maturation (IVM), fertilization (IVF), and in vitro cultivation (IVC). Although the rate of blastocyst production is influenced by the origin and quality of the oocytes used in in vitro production, it is known that the quality of embryos produced is directly related to embryonic culture conditions (Rizos et al, 2002; Lonergan et al., 2006; Maziero et al., 2020). This is due to changes in oxidative profiles due to fluctuating concentrations of oxygen during the production process. It is known that intrauterine oxygen concentrations are 2-8\%, whereas atmospheric levels are $20 \%$. When embryos are grown in an atmosphere with high oxygen content, oxidative stress conditions increase, causing an imbalance between pro-oxidant levels (ROS, reactive oxygen species, free radicals) and antioxidant abundance (Rocha-Frigoni et al., 2013).

Hence, to reduce the deleterious effects of ROS on in vitro production embryo, antioxidants are added to embryo culture media in vitro (Lira et al., 2020). Melatonin is a lipophilic molecule derived from tryptophan, present in vertebrates, invertebrates, bacteria, single-celled organisms and plants. Melatonin is produced by the pineal gland (main site), cerebellum, retina, skin, gastrointestinal cells, Harder gland, thymus, peripheral mononuclear cells, placenta, ovary, testicle, bone marrow, liver, hippocampus, and platelets (Mayo et al., 2018). Melatonin is not stored, but directly secreted both to the cerebrospinal fluid and the cardiovascular system. Thus, it can migrate freely through morphophysiological barriers such as the blood-brain barrier and placenta; therefore, it can be distributed throughout the entire body (Iwasaki et al., 2005). In mammals, melatonin performs a series of biological functions such as regulation of circadian cycles and seasonal signaling for reproduction, and has antioxidant and immunomodulatory effects (Mayo et al., 2018).

The antioxidant action of melatonin is a good alternative to the in vitro production of bovine embryos. When used during the embryo maturation and cultivation processes, there are decreases in ROS and DNA fragmentation in oocytes and blastocysts (Asgari et al., 2012; Takada et al., 2010; Takada et al., 2012). However, few results have been described in the literature, especially regarding melatonin concentration to be used.

Therefore, in this study, we sought to evaluate the effects of adding $50 \mathrm{ng} / \mathrm{mL}$ melatonin to culture systems with in vitro production embryo mineral oil on embryonic production.

\section{Methodology}

Ovaries of cows intended for commercial slaughter were used, with eight routines were performed (320 oocytes per routine). The ovaries were transported to an in vitro embryo production laboratory located in Moreira Sales, Paraná. In the laboratory, the ovaries were washed with $0.9 \%$ sodium chloride solution at a temperature of $37^{\circ} \mathrm{C}$ to $38^{\circ} \mathrm{C}$. After washing, ovarian follicles with a diameter between 2 and $8 \mathrm{~mm}$ were aspirated with the aid of a $10 \mathrm{~mL}$ syringe fitted with $21 \mathrm{G}$ needles. The follicular fluid was then held in $15 \mathrm{~mL}$ tubes to form a sediment at $37.5^{\circ} \mathrm{C}$ for $10 \mathrm{~min}$. Oocyte selection was performed in HEPES medium (TCM 199 HEPES), obtaining only oocyte cumulus complexes (COCs) with three or more layers of cumulus cells and homogeneous cytoplasm.

Selected COCs were washed $(3 \times$ MIV HEPES; $3 \times$ MIV medium) and divided into groups of 25 oocytes per $90 \mu \mathrm{L}$ drop of MIV under mineral oil. After $24 \mathrm{~h}$ of incubation at $38.5^{\circ} \mathrm{C}, 5 \% \mathrm{CO}_{2}$ in air, and $100 \%$ relative humidity, the matured oocytes were washed in HEPES medium and transferred in groups of 25 to IVF drops ( $90 \mu \mathrm{L} / \mathrm{drop}$ ).

To carry out fertilization, a straw of bull semen with known fertility was thawed. Viable sperm were selected using a continuous Percoll density gradient (45\% and 90\%). The oocytes were fertilized with a dose of $1 \times 10^{6} \mathrm{sperm} / \mathrm{mL}$ and incubated for $18 \mathrm{~h}$ under the conditions described above. 
After IVF, the zygotes were mechanically stripped with the aid of a pipette and transferred to in vitro culture. The groups were divided into control and melatonin groups. Drops with 15 oocytes of SOFaa medium ( $90 \mu \mathrm{L} / \mathrm{drop}$ ) were placed in Petri dishes, divided into a control group (without melatonin supplementation) and a melatonin group (supplemented with 50 $\mathrm{ng} / \mathrm{mL}$ melatonin) and incubated under mineral oil at $38.5^{\circ} \mathrm{C}, 5 \% \mathrm{CO}_{2}$ in air, and $100 \%$ humidity. On D4.5, cleavage was verified, and on $\mathrm{D} 7$, the rate of blastocyst formation was evaluated.

For statistical analyses, ANOVA using PROC GLM of SAS (SAS Inst. Inc., Cary, NC, USA) was used. Sources of variation in the model including treatment and replicates were considered as fixed and random effects, respectively. Data are presented as means \pm standard deviations. For all analyses, a statistical significance level of $5 \%$ was adopted.

\section{Results}

The cleavage rates assessed on D3 are shown in Table 1. There was no difference between the groups, with the control group presenting $86.83 \pm 3.2 \%$ and the melatonin group exhibiting a cleavage rate of $87.20 \pm 4.8 \%$.

Table 1. Average (\%) of the percentage of cleavage / oocytes on day three (D3) of embryonic development between the control group (C) and the melatonin group (Mel).

\begin{tabular}{lcc}
\hline Treatment & Oocytes number & Cleavage percentage $(\%)$ \\
\hline Control & 1276 & $86,83 \pm 1,6^{\mathrm{a}}$ \\
Melatonin & 1315 & $87,20 \pm 2,1^{\mathrm{a}}$ \\
\hline
\end{tabular}

\footnotetext{
${ }^{\mathrm{ab}}$ Means with unusual envelopes in the same column differ $(\mathrm{P}<0.05)$. Source: Authors.
}

For the rate of embryo formation, there was also no difference between groups, control group: $44.4 \pm 2.1 \%$ of blastocysts and melatonin group: $41.5 \pm 1.5 \%$ of blastocysts, as shown in Table 2 .

Table 2. Blastocyst formation rate (\%) assessed at D7, in the control and melatonin groups.

\begin{tabular}{|c|c|c|c|c|c|c|c|}
\hline \multirow{2}{*}{ Groups } & \multicolumn{5}{|c|}{ Blastocyst production (\%) } & \multirow[t]{2}{*}{ Total } & \multirow[t]{2}{*}{$\%$} \\
\hline & $\mathrm{Eb}$ & B & $\mathrm{Xb}$ & $\mathrm{Hnb}$ & $\mathrm{Hb}$ & & \\
\hline Control & $4,6 \pm 1,2^{\mathrm{a}}$ & $14,7 \pm 1,5^{\mathrm{a}}$ & $12,1 \pm 1,9^{\mathrm{a}}$ & $13,1 \pm 1,6^{\mathrm{a}}$ & $3,2 \pm 1,2^{\mathrm{a}}$ & 960 & $44,4 \pm 2,1^{\mathrm{a}}$ \\
\hline Melatonin & $3,2 \pm 1,7^{\mathrm{a}}$ & $13,1 \pm 1,8^{\mathrm{a}}$ & $12,6 \pm 1,5^{\mathrm{a}}$ & $11,5 \pm 1,6^{\mathrm{a}}$ & $1,1 \pm 1,9^{\mathrm{a}}$ & 952 & $41,5 \pm 1,5^{\mathrm{a}}$ \\
\hline
\end{tabular}

Embryo development stage evaluated on day 7: Eb, early blastocyst; B, blastocyst; Xb, expanded blastocyst; Hnb, blastocyst hatching; Hb, hatched blastocyst. Mean \pm standard error

${ }^{a b}$ Means with unusual envelopes in the same column differ $(\mathrm{P}<0.05)$.

Source: Authors.

\section{Discussion}

The results obtained in this study showed that the addition of $50 \mathrm{ng} / \mathrm{mL}$ melatonin to bovine embryo culture medium did not increase the rate of embryo production, which was similar to the control group. Contradictory results have been previously reported with the use of melatonin in the culture medium at different doses and treatment durations. The different embryo culture systems are also questionable, as melatonin has lipophilic characteristics, which can interfere with its action in systems involving mineral oil, as reported earlier by Assis (2014). It is known that the presence of mineral oil in the system can lead to impaired melatonin action. 
In cattle, one of the first studies that tested melatonin in embryonic culture used a dose of $10^{-4} \mathrm{M}$, with an increase in the rate of blastocyst formation in ambient atmospheric conditions with $20 \% \mathrm{O}_{2}(68.9 \%$ melatonin vs. 50.8\% control) (Papis et al., 2007). Studies in swine have yielded improvements in in vitro embryo production with the use of melatonin (1 nM) in embryonic culture in a system with mineral oil, increasing the cleavage and blastocyst rates. However, the genes involved in antioxidant or pro-action were not evaluated as oxidants (Rodrigues et al., 2008).

Many different free radical scavengers have been investigated for potential protection against oxidative stress in mammalian embryos subjected to in vitro culture systems. Starting with extracellular enzymes such as superoxide dismutase or catalase, other systems including taurine/hypotaurine, thioredoxin, pyruvate or low molecular weight thiols such as $\beta$ mercaptoethanol, glutathione, and cysteine were tested (Guérin et al., 2001).

Zhao et al. (2015) showed the effect of adding $10^{-9} \mathrm{M}$ melatonin to IVM and the potential for development of denuded bovine oocytes of cumulus oophorus (discus proligerus). These authors found that melatonin significantly increases the frequency of oocytes in metaphase II, decreases the level of reactive oxygen species (ROS), and moderates reductions in the relative levels of ATP6, ATP8, BMP-15, and GDF-9 mRNAs caused by the denudation of oocytes. Melatonin also significantly increases the rate of embryonic development and the levels of expression of IFN- $\tau, \mathrm{Na}^{+} / \mathrm{K}^{+}, \mathrm{ATPase}, C T N N B L 1$, and AQP3 mRNAs in blastocysts. By adding 10 or $50 \mathrm{ng} / \mathrm{mL}$ of melatonin to the IVM medium in an oil-free system. El-Raey et al. (2011) obtained an increase in oocyte nuclear maturation, as well as increased cumulus cell expansion and decreased levels of EROS in oocytes compared to controls.

Other authors have shown that the addition of melatonin at a concentration of $10^{-6} \mathrm{M}$ protects oocytes against damage caused by thermal shock (Paula, 2007). Assis (2014) found that melatonin exhibits stable behavior under embryo culture conditions with or without oil, with antioxidant action at a dose of $50 \mathrm{ng} / \mathrm{mL}$. There was also an increase in the production and quality of embryos in vitro with culture medium supplemented with melatonin and subjected to induced oxidative stress.

When used in the in vitro production of embryos during embryo maturation and culture, melatonin decreases EROS and DNA fragmentation in oocytes and blastocysts (Rodrigues et al., 2007); Asgari et al., 2012). However, there is still no well-established optimal melatonin dose because the results of cleavage and formation of blastocysts are similar to those of control groups.

According to Takada et al. (2010) supplementation with a physiological concentration of melatonin $\left(10^{-9} \mathrm{M}\right)$ in in vitro maturation medium with or without a combination of gonadotropins has no effect on nuclear maturation or on rates of cleavage and blastocyst formation. These rates ranged from $88 \%$ to $90 \%, 85 \%$ to $88 \%$, and $42 \%$ to $46 \%$, respectively. These data corroborate the present study, in which the use of melatonin in the culture medium did not enhance the embryonic development index. In contrast, the positive effects of melatonin on nuclear maturation and embryonic development were reported by Kang et al. (2009) in pigs and by Manjunatha et al. (2009) in buffalos.

Tsantarioutou et al. (2007) did not observe differences in bovine cleavage rates or in blastocyst production frequency when melatonin was added to the IVM medium, which was similar to the findings of the present study. According to a number of authors, embryo culture conditions are well established in cattle (Papis et al., 2007; Parrish et al., 1994; Holm et al. 1999; Sagirkaya et al., 2007; Adona et al., 2008; Corrêa et al., 2008). Some of the obstacles to the full success of in vitro embryo production are events that occur in the oocytes during the IVM period. Oocyte maturation is a process in which cells acquire an intrinsic capacity for gradual development until reaching activation of the embryonic genome (Maziero et al., 2016).

Cebrian-Serrano et al. (2013) evaluated the effects of adding melatonin to the IVM medium of bovine oocytes subjected to thermal shock in terms of production rates and quality of blastocysts. These authors found that $10^{-4} \mathrm{M}$ melatonin was alleviate bovine oocytes from harmful effects of heat stress. In addition, Lira et al. (2020) found that the $10^{-4} \mathrm{M}$ 
concentration resulted in better embryonic quality. However, in our study, where melatonin was added to the IVC medium only, we did not observe any improvement in the rate of embryonic production by D7.

\section{Conclusion}

In conclusion, the addition of $50 \mathrm{ng} / \mathrm{mL}$ melatonin to the culture medium of bovine embryos did not improve the rate of blastocyst formation. Thus, the beneficial effects of melatonin in increasing the in vitro production of bovine embryos should be further studied and, in particular, the ideal concentration required in embryonic culture media for improved in vitro production embryos outcomes should be deduced.

\section{Acknowledgement}

Universidade Paranaense (UNIPAR) and Fundação Araucária for granting the Scientific Initiation Scholarship PEBIC (External Scientific Initiation Scholarship Project), to student Ricardo Magalhães.

\section{References}

Adona, P. R.; Pires, P. R. L.; Quetglas, M. D.; Schwarz, K. R. L.; \& Leal, C. L. V. (2008). Nuclear maturation kinetics and in vitro embryo development of cattle oocytes prematured with butyrolactone. I. combined or not combined with roscovitine. Animal Reproduction Science 104: $389-397$.

Asgari, Z.; Ghasemian, F.; Ramezani, M.; \& Bahadori, M. H. (2012). The effect of melatonin on the developmental potential and implantation rate of mouse embryos. Cell Journal 14(3): 203-208.

Assis, P. M. (2014). Melatonina no meio de cultivo in vitro de embriões bovinos: dinâmica e ação antioxidante. Dissertação. Pós-Graduação em Reprodução Animal da Faculdade de Medicina Veterinária e Zootecnia. Universidade de São Paulo. 2014.

Cebrian-Serrano, A.; Salvador, I.; Raga, E.; Dinnyes, A.; \& Silvestre, A. (2013). Beneficial Effect of Melatonin on Blastocyst In Vitro Production from HeatStressed Bovine Oocytes. Reproduction in Domestic Animals 48:738-746.

Corrêa, G. A.; Rumpf, R.; Mundim, T. C. D.; Franco, M. M.; \& Dode, M. A. N. (2008). Oxygen tension during in vitro culture of bovine embryos: effect in production and expression of genes related to oxidative stress. Animal Reproduction Science 104:132-142.

El-Raey, M.; Geshi, M.; Somfai, T.; Kaneda, M.; Hirako, M.; Abdel- Ghaffar, A. E.; Sosa, G. A.; El-Roos, M. E. A. A.; \& Nagai, T. (2011). Evidence of melatonin synthesis in the cumulus oocyte complexes and its role in enhancing oocyte maturation in vitro in cattle. Molecular, Reproduction and Development $78(4): 250-262$.

Gonçalves, R. L. R. \& Vianna, J. H. M. (2019). Situação atual da produção de embriões bovinos no Brasil e no mundo. Anais do XXIII Congresso Brasileiro de Reprodução Animal (CBRA-2019), Gramado, RS, 2019.

Guérin, P.; El, Mouatassim. S.; \& Ménézo, Y. (2001). Oxidative stress and protection against reactive oxygen species in the preimplantation embryo and its surroundings. Human Reproduction Update 7:175-189.

Holm, P.; Booth, P. J.; Schimid, T. M. T.; Greve, T.; \& Callesen, H. (1999). High bovine blastocyst development in a static in vitro production system using SOFaa medium supplemented with sodium citrate and myo-inositol with or without serum proteins. Theriogenology 52: 683-700.

Iwasaki, S.; Nakazawa, K.; Sakai, J.; Kometani, K.; Iwashita, M.; Yoshimura, Y.; \& Maruyama, T. (2005). Melatonin as a local regulator of human placental function. Journal of Pineal Research 39:261-265.

Kang, J. T.; Koo, O. J.; Kwon, H. J.; Park, H. J.; Jang, G.; Kang, S. K.; \& Lee, S. C. (2009). Effects of melatonin on in vitro maturation of porcine oocyte and expression of melatonin receptor RNA in cumulus and granulosa cells. Journal of Pineal Research 46: 22-28.

Lira, A. S.; Chaves, R. M.; Moraes Junior, F. J.; Costa Junior, S. H.; Amaral, B. K. L.; \& Trovão, H. M. P. (2020). Use of melatonin in the in vitro production of bovine embryos. Revista Brasileira em Saúde e Produção Animal 21(1-9): e210322020.

Lonergan, P.; Fair, T.; Corcoran, D.; \& Evans, A. C. O. (2006). Effect of culture environment on gene expression and developmental characteristics in IVFderived embryos. Theriogenology 65:137-152.

Manjunatha, B. M.; Devaraj, M.; Gupta, P. S. P.; Ravindra, J. P.; \& Nandi, S. (2009). Effect of taurine and melatonin in the culture medium on buffalo in vitro embryo development. Reproduction in Domestic Animal 44:12-16.

Mayo, J. C.; Aguado, A.; Cernuda-Cernuda, R.; Artime, A. A.; Cepas, V.; Quiros-González, I.; Hevia, D.; \& Sáinz, R. M. (2018). Melatonin Uptake by Cells: An Answer to Its Relationship with Glucose? Molecules 23(8):1999.

Maziero, R. R. D.; Guaitolini, C. R. F.; Paschoal, D. M.; Crespilho, A. M.; Sestari, D. A. O.; Dode, M. A. N.; \& Landim-Alvarenga, F. C. (2020). Effects of the addition of oocyte meiosis-inhibiting drugs on the expressionof maturation-promoting factor components and organization ofcytoplasmic organelles. Reproductive Biology 20:48-62. 
Research, Society and Development, v. 10, n. 6, e19010615544, 2021

(CC BY 4.0) | ISSN 2525-3409 | DOI: http://dx.doi.org/10.33448/rsd-v10i6.15544

Maziero, R. R. D.; Guaitolini, C. R. F.; Paschoal, D. M.; Kievitsbosch, T.; Guastali, M. D.; Moraes, C. N.; \& Landim-Alvarenga, F. C. (2016). Effect of temporary meiotic attenuation of oocytes with butyrolactone-I and roscovitine in resistance to bovine embryos on vitrification. Reproduction in Domestic Animal 51: 204-2011.

Papis, K.; Poleszczuk, O.; Wenta-Muchalska, E.; \& Mondlinski, J. A. (2007). Melatonin effect on bovine embryo development in vitro in relation to oxygen concentration. Journal of Pineal Research 43:321-326.

Parrish, J. J.; Krogenaes, A.; \& Susko-Parrish, J. L. (1994). Effect of bovine sperm separation by either swim-up and percoll method on success of in vitro fertilization and early embryonic development. Theriogenology 44: 859-869.

Paula, F. A. P. (2017). Efeito da melatonina na maturação in vitro sobre a expressão gênica e a qualidade de oócitos bovinos sob choque térmico. Dissertação (Mestrado) apresentada à Universidade Federal de Lavras, 98p., 2017.

Pontes, J. H. F.; Nonato-Junior, I.; Sanches, B. V.; Ereno-Junior, J. C.; Uvo, S.; Barreiros, T. R. R.; Oliveira, J. A.; Hasler, J. F.; \& Seneda, M. M. (2011). Comparison of embryo yield and pregnancy rate between in vivo and in vitro methods in the same Nelore (Bos indicus) donor cows. Theriogenology, 71(4):690-697.

Rizos, D.; Ward, F.; Duffy, P.; Boland, M. P.; \& Lonergan, P. (2002). Consequences of bovine oocyte maturation, fertilization and early embryo development in vitro versus in vivo: implication for blastocyst yield and blastocyst quality. Molecular, Reproduction and Development 61:234-248.

Rocha-Frigoni, N. A. D. S.; Leão, B. C. D. S.; Nogueira, E.; Accorsi, M. F.; \& Mingoti, G. Z. (2013). Effects of gaseous atmosphere and antioxidants on the development and cryotolerance of bovine embryos at different periods of in vitro culture. Zygote 41:1-10.

Rodriguez-Osorio, N.; Kim, I. J.; Wang, H.; Kaya, A.; \& Memili, E. (2007). Melatonin increases cleavage rate of porcine preimplantation embryos in vitro. Journal of Pineal Research 43(3): 283-288.

Sagirkaya, H.; Misirlioglu, M.; Kaya, A.; First, N. L.; Parrish, J. J.; \& Memili, E. (2007). Developmental potential of bovine oocytes cultured in different maturation and culture conditions. Animal Reproduction Science 101:225-240.

Sudano, M. J.; Paschoal, D. M.; Rascado, T. S.; Magalhães, L. C. O.; Crocomo, L. F.; Lima-Neto, J. F.; \& Landim-Alvarenga, F. C. (2011). Lipid content and apoptosis of in vitro-produced bovine embryos. Theriogenology 5:1211-1220.

Takada, L.; Junior, A. M.; Mingoti, G. Z.; Balieiro, J. C.; Cipolla-Neto, J.; \& Coelho, L. A. (2012). Effect of melatonin on DNA damage of bovine cumulus cells during in vitro maturation (IVM) and on in vitro embryo development. Research and Veterinary Science 92:124-127.

Takada, L.; Martins Junior, A.; Mingoti, G. Z.; Balieiro, J. C. J.; \& Coelho, L. A. (2010). Melatonin in maturation media fails to improve oocyte maturation, embryo development rates and DNA damage of bovine embryos. Scientia Agricola 67(1): 393-398.

Tsantarioutou, M. P.; Altanasio, L.; De Rosa, A.; Boccia, L.; Pellerano, G.; \& Gasparrini, B. (2007). The effect of melatonin on bovine in vitro embryo development. Italian Journal of Animal Science 6:488-489.

Viana, J. H. M. (2018). Statistics of embryo production and transfer in domestic farm animals: Is it a turning point? In 2017 more in vitro-produced than in vivo-derived embryos were transferred worldwide. Embryo Transfer Newsletters 36(4):8-25.

Zhao, X. M.; Min, J. T.; Du, W. H.; Hao, H. S.; Liu, Y.; Qin, T.; Wang, D.; \& Zhu, H. B. (2015). Melatonin enhances the in vitro maturation and developmental potential of bovine oocytes denuded of the cumulus oophorus. Zygote 23(4): 1-12. 